\title{
Faktor Penyebab Kurangnya Kinerja Surveilans Infeksi Nosokomial di RSUD Dr. Iskak Tulungagung
}

\section{The Causes of Low Performance on Nosocomial Infection Surveillance at Dr. Iskak Hospital Tulungagung}

\author{
Dewi Lelonowati TM', Mulyatim Koeswo', Kasil Rokhmad² \\ ${ }^{1}$ Program Studi Magister Manajemen Rumah Sakit Fakultas Kedokteran Universitas Brawijaya Malang \\ ${ }^{2}$ Rumah Sakit Umum Daerah Dr Iskak Tulungagung
}

\begin{abstract}
ABSTRAK
Surveilans infeksi nosokomial merupakan salah satu kegiatan dalam program Pencegahan dan Pengendalian Infeksi (PPI) di rumah sakit. Pada studi pendahuluan menunjukkan kegiatan pencatatan dan pelaporan infeksi nosokomial di RSUD Dr. Iskak Tulungagung (minimal 1 parameter) jauh lebih rendah dari Standar Pelayanan Minimal (SPM), meskipun sudah tersedia Tim PPI yang terlatih. Hal ini mengindikasikan kinerja surveilans infeksi nosokomial belum berjalan dengan baik. Tujuan dari penelitian ini adalah untuk mengidentifikasi, menganalisis dan menentukan solusi dari faktor penyebab kurangnya kinerja surveilans infeksi nosokomial di RSUD Dr. Iskak Tulungagung. Penelitian ini dilakukan dengan pendekatan deskriptif kualitatif dengan mempelajari dokumen-dokumen, wawancara terstruktur dan observasi dengan checklist. Pencarian akar masalah dilakukan dengan melakukan Focus Group Discussion dengan peserta 19 perawat Infection Prevention Control Nurse (IPCN) dan Infection Prevention Control Link Nurse (IPCLN). Hasil penelitian menunjukkan sebagian besar komponen surveilans infeksi nosokomial belum dijalankan dengan benar sesuai Petunjuk Teknis Surveilans dari Kemenkes tahun 2010. Hal tersebut disebabkan belum adanya kebijakan untuk sosialisasi program kepada Tim PPI, kurangnya dukungan manajemen terhadap program dan sarana penunjang, serta belum adanya fungsi pengawasan terhadap pelaksanaan program surveilans infeksi nosokomial. Kesimpulan hasil tapisan pilihan solusi terbaik dengan metode Nominal Group Technique (NGT) dan metode CARL adalah pengadaan program pendidikan dan pelatihan yang berkesinambungan kepada Tim PPI untuk meningkatkan pengetahuan, ketrampilan dan sikap demi menunjang keberhasilan program surveilans infeksi nosokomial di rumah sakit.
\end{abstract}

Kata Kunci: Pendidikan dan pelatihan, surveilans infeksi nosokomial, Tim PPI

\begin{abstract}
Surveillance on nosocomial infection is one of the activities in Prevention and Infection Control Program (PPI Program) in hospital. Preliminary study shows the activity of recording and reporting of nosocomial infection in Dr. Iskak hospital Tulungagung (at least 1 parameter) was much lower than the minimum service standards, although trained PPI team was available. This indicates that the performance of surveillance of nosocomial infection has not run well. The purpose of this study is to identify, analyze, and determine the solution from the causes of the low performance of surveillance of nosocomial infection in Dr. Iskak hospital Tulungagung. The study was conducted with a qualitative descriptive approach to study the documents, structurally interview, and observe with checklist. Problem searching was conducted using Focus Group Discussion with 19 nurses of Infection Prevention Control Nurse (IPCN) and Infection Prevention Control Link Nurse (IPCLN) as participants. The results show most components of surveillance have not been executed properly according to the Technical Guidelines of the Ministry of Health Surveillance 2010. It is caused by the absence of policies for program socializing to PPI Team, lack of management support for the program and supporting facilities, as well as the lack of oversight of the implementation of nosocomial infection surveillance program. The best solution with Nominal Group Technique (NGT) and CARL method is the establishment of an education program and continuous training for PPI team to improve the knowledge, skills, and attitudes to support the surveillance program of HAls in Dr. Iskak hospital Tulungagung.
\end{abstract}

Keywords: Education and training, PPI team, surveillance of nosocomial infection

Jurnal Kedokteran Brawijaya, Vol. 28, Suplemen No. 2, 2015; Korespondensi: Dewi Lelonowati TM. Program Studi Magister Manajemen Rumah Sakit Fakultas Kedokteran Universitas Brawijaya Malang, Jl. Veteran Malang 65145 Tel. (0341) 569117 Email: dewilelonowati@yahoo.co.id 


\section{PENDAHULUAN}

Infeksi yang terjadi di rumah sakit disebut juga infeksi nosokomial atau Hospital Acquired Infections (HAl's) merupakan problem yang serius bagi kesehatan masyarakat (1). Menurut WHO (2011) HAI's merupakan infeksi yang didapat pasien selama menjalani prosedur perawatan dan tindakan medis di pelayanan kesehatan setelah $\geq 48$ jam dan setelah $\leq 30$ hari setelah keluar dari fasilitas kesehatan (2,3). Program Pencegahan dan Pengendalian Infeksi (PPI) sangat penting untuk dilaksanakan di rumah sakit sebagai tempat pelayanan kesehatan sebagai tolok ukur mutu pelayanan juga untuk melindungi pasien, petugas, pengunjung dan keluarga dari risiko tertularnya infeksi (4). Infeksi yang terjadi di rumah sakit tidak saja dapat dikendalikan tetapi juga dapat dicegah dengan melakukan langkah-langkah yang sesuai dengan prosedur yang berlaku $(5,6)$. Untuk meminimalkan risiko terjadinya infeksi di rumah sakit dan fasilitas pelayanan kesehatan lainnya perlu diterapkan program Pencegahan dan Pengendalian Infeksi (PPI), yaitu kegiatan yang meliputi perencanaan, pelaksanaan, pembinaan, pendidikan dan pelatihan, serta monitoring dan evaluasi $(4,7)$.

Menurut Alvarado angka infeksi nosokomial terus meningkat mencapai sekitar 9\% (variasi 3-21\%) atau lebih dari 1,4 juta pasien rawat inap di rumah sakit seluruh dunia $(5,6)$. Hasil survey point prevalence dari 11 rumah sakit di DKI Jakarta yang dilakukan oleh Perdalin Jaya dan Rumah Sakit Penyakit Infeksi Prof. Dr. Sulianti Saroso Jakarta pada tahun 2003, didapatkan angka infeksi nosokomial untuk ILO (Infeksi Luka Operasi) 18,9\%, ISK (Infeksi Saluran Kemih) 15,1\%, IADP (Infeksi Aliran Darah Primer) 26,4\%, Pneumonia 24,5\% dan Infeksi Saluran Napas lain 15,1\%, serta Infeksi lain 32,1\% $(5,6)$. Selama $10-$ 20 tahun belakangan ini telah banyak perkembangan yang dibuat untuk mencari masalah utama meningkatnya angka kejadian infeksi nosokomial di banyak negara, namun kondisinya justru masih sangat memprihatinkan $(8,9)$.

Surveilans adalah suatu kegiatan yang dilaksanakan secara terus menerus dan sistematik dalam bentuk pengumpulan data, analisis data, interpretasi data dan diseminasi informasi hasil interpretasi data bagi mereka yang membutuhkan $(5,7)$. Hasil ini penting untuk perencanaan, penerapan, evaluasi dan praktek-praktek pengendalian infeksi bagi pemegang kebijakan. Kegiatan surveilans infeksi nosokomial dilaksanakan untuk mencapai tujuan utama dari program pengendalian infeksi di rumah sakit yaitu mengurangi risiko terjadinya endemik dan epidemik kejadian infeksi nosokomial pada pasien.

Surveilans infeksi nosokomial merupakan salah satu jenis dari surveilans epidemiologi, maka ada 5 komponen utama: 1) pengumpulan data, 2) pengelolaan data, 3) analisis dan interpretasi data, 4) distribusi data dan 5) evaluasi (10). Berdasarkan Keputusan Menteri Kesehatan No. 270/Menkes/SK/III/2007 tentang Pedoman Manajerial Pencegahan dan Pengendalian Infeksi di Rumah Sakit dan Fasilitas Kesehatan lainnya, bahwa keberhasilan program PPI di Rumah Sakit perlu keterlibatan lintas profesional, Klinis, Perawat, Laboratorium, K3L, Farmasi, Gizi, IPSRS, Sanitasi dan House Keeping sehingga perlu wadah berupa Komite PPI (5). Dalam Komite PPI anggotanya harus saling bekerjasama dan perlu dukungan dari manajerial untuk terlaksananya program PPI dengan baik (11). Pelaksanaan PPI di rumah sakit dan fasilitas pelayanan kesehatan lainnya harus dikelola dan diintegrasikan antara struktural dan fungsional dari semua departemen/instalasi/divisi/ unit di rumah sakit dan fasilitas pelayanan kesehatan lainnya sesuai dengan falsafah dan tujuan PPI (5).

Dessler mendefinisikan kinerja sebagai perbandingan antara hasil kerja yang secara nyata dengan standar kerja yang ditetapkan, kinerja lebih memfokuskan pada hasil kerjanya (12). Berdasarkan pengertian tersebut, kinerja mengandung 3 (tiga) unsur yaitu: 1) unsur waktu dalam arti hasil yang dicapai oleh usaha tertentu dinilai dalam satu putaran waktu (periode) yang diukur menggunakan satuan jam, hari, bulan maupun tahun; 2) unsur hasil dalam arti hasil rata-rata yang dicapai pada akhir periode tersebut; 3 ) unsur metode dalam arti karyawan menguasai betul dan bersedia mengikuti pedoman metode yang telah ditentukan, yaitu metode kerja yang efektif dan efisien dan bekerja penuh gairah dan tekun. Dalam hal ini kinerja surveilans infeksi nosokomial di RSUD Dr. Iskak Tulungagung dikatakan belum baik karena belum memenuhi ketiga unsur tersebut.

RSUD Dr. Iskak merupakan rumah sakit umum milik Pemerintah Kabupaten Tulungagung di propinsi Jawa Timur yang berstatus Badan Layanan Umum Daerah (BLUD), memiliki 393 tempat tidur dan bertipe rumah sakit Kelas B Non Pendidikan. Salah satu misi rumah sakit adalah melaksanakan pelayanan kesehatan secara paripurna, maka rumah sakit dituntut untuk dapat memberikan pelayanan yang bermutu sesuai dengan standar. Gambaran tingkat pemanfaatan dan efisiensi sarana pelayanan serta mutu pelayanan pada tahun 2013 meliputi Bed Occupancy Rate (BOR) 76,61\%, Length of Stay (LOS) 4,29 hari, Bed Turn Over (BTO) 65,24 kali dan Turn Over Interval (TOI) 1,31 hari. Pada tahun 2013 jumlah kunjungan rawat jalan adalah 163.458 pasien, kunjungan rawat inap 25.641 pasien dan kunjungan Instalasi Gawat Darurat (IGD) 36.744 pasien dengan tren yang semakin meningkat dari tahun-tahun sebelumnya. Persentase pasien rawat inap yang meninggal tahun 2013 meningkat $0,65 \%$ dibandingkan tahun 2012. Nilai GDR atau angka kematian umum tahun 2013 lebih dari 45\%o (ambang batas SPM) yaitu sebesar $73,44 \%$, begitu pula nilai NDR atau angka kematian 48 jam setelah dirawat sebesar 46,64\%o (lebih dari 25\%o) mengalami kenaikan bila dibandingkan dari tahun 2012 sebesar 28,36\%. Pada data pencapaian pelayanan rawat inap juga didapatkan penyebab kematian terbanyak karena septicaemia unspecified, sehingga perlu kiranya diwaspadai kemungkinan meningkatnya insiden infeksi nosokomial yang terjadi.

Program PPI di RSUD Dr. Iskak Tulungagung sudah ada penetapan dalam Surat Keputusan Direktur Nomor 188.4/59/206/2010 tentang Komite Pengendalian Infeksi Nosokomial dan Tim Pengendalian Infeksi Nosokomial serta Surat Keputusan Direktur Nomor 188.4/13.B/206/2010 tentang Penunjukan Perawat Pengendali Infeksi. Kegiatan pencatatan dan pelaporan infeksi nosokomial di RS (minimal 1 parameter) tahun 2013 masih kurang memuaskan karena hanya tercapai $15,38 \%$ dari target SPM $\geq 80 \%$. Mengingat pentingnya surveilans infeksi nosokomial dalam upaya untuk pencegahan dan pengendalian infeksi, serta dalam rangka persiapan akreditasi dari KARS versi 2012 pada akhir tahun 2014, perlu dilakukan evaluasi pada kinerja surveilans infeksi 
nosokomial di RSUD Dr. Iskak Tulungagung.

Tujuan dari penelitian ini untuk mengidentifikasi faktorfaktor penyebab kurangnya kinerja surveilans infeksi nosokomial oleh pelaksana program PPI, memberikan alternatif solusi terbaik dan memberikan rekomendasi atas permasalahan surveilans infeksi nosokomialdi RSUD Dr. Iskak Tulungagung. Penelitian ini diharapkan dapat membantu terselenggaranya kegiatan surveilans infeksi nosokomial secara benar dan efektif sesuai pedoman dalam Petunjuk Praktis Surveilans Infeksi Nosokomial dari Depkes RI tahun 2010 untuk mengurangi angka kematian pasien rawat inap dan angka kejadian infeksi nosokomial di rumah sakit.

\section{METODE}

Penelitian ini dilakukan secara deskriptif kualitatif untuk mengamati proses kegiatan surveilans di ruang rawat inap dalam hal pengumpulan data sampai evaluasinya. Metode yang digunakan dengan wawancara ditunjang observasi terhadap pelaksana surveilans di ruang rawat inap, staf di unit Rekam Medik untuk pengelolaan dan analisis data. Wawancara terstruktur dengan checklist dilakukan kepada Ketua Komite PPI, 2 orang perawat IPCN (Infection Prevention Control Nurse) dan 10 orang perawat IPCLN (Infection Prevention and Control Link Nurse) untuk menilai tugas dan tanggungjawab mereka sebagai pelaksana program PPI khususnya kegiatan surveilans infeksi nosokomial. Untuk menilai sejauh mana dukungan kebijakan manajemen rumah sakit dilakukan dengan metode wawancara terstruktur dengan checklist terhadap 19 orang IPCN dan IPCLN. Untuk mencari akar penyebab masalah dilakukan dengan Focused Group Discussion (FGD) dengan peserta 19 orang perawat IPCN dan IPCLN dengan alat bantu diagram Fishbone dan dilanjutkan dengan tehnik bertanya " 5 Why". Tehnik mencari pemecahan masalah/alternatif solusi dengan metode Nominal Group Tecnique (NGT) pada Ketua Komite PPI, wakil IPCN dan wakil IPCLN, kemudian ditapis lagi dengan metode CARL (Capasity, Accessibility, Readiness, Leverage) dengan nilai skala 1-4 untuk mencari solusi terbaik.

\section{HASIL}

Tugas Komite dan Tim PPI pada Surveilans Infeksi Nosokomial

Hasil pengamatan terhadap kegiatan surveilans oleh tim PPI (IPCN dan IPCLN) yang meliputi komponen pengumpulan data; pengolahan dan penyajian data; analisis dan interpretasi data; kegiatan pelaporan, rekomendasi dan diseminasi informasi didapatkan bahwa semua pelaksanaannya belum dilakukan sesuai Petunjuk Praktis Surveilans Infeksi di Rumah sakit dari Kementerian Kesehatan RI tahun 2010. Pengumpulan data dengan pengisian formulir surveilans oleh perawat IPCLN di tiap ruang rawat inap belum semuanya lengkap. Perawat IPCLN banyak yang tidak tahu tentang penentuan kriteria suspek infeksi nosokomial (Infeksi Aliran Darah Perifer (IADP), Infeksi Saluran Kencing (ISK), Ventilator Associated Pnemonia (VAP)/Hospital Associated Pneumonia (HAP), dII). Cara pengisian formulir surveilans masih banyak yang salah. Rekap formulir surveilans yang sudah diisi datadata pasien, tiap awal bulan diberikan ke unit Rekam Medik bukan kepada IPCN untuk dianalisis. IPCN tidak melakukan tugasnya mengawasi kegiatan surveilans di ruang rawat inap tiap hari, karena kesibukan mereka yang merangkap tugas fungsional lain (sebagai perawat/kepala ruang rawat inap).

Proses pengelolaan, analisa dan interpretasi data tidak dilakukan oleh IPCN tapi oleh unit Rekam Medik sehingga informasi yang dihasilkan menjadi kurang akurat. Tim PPI belum melakukan tugas dan tanggungjawab yang telah ditetapkan. Perawat IPCN belum menyusun laporan incidence rate infeksi nosokomial yang dilakukan selama kurun waktu 1 bulan, 3 bulan, semester dan tahunan. Tugas dan tanggungjawab yang belum dilakukan Komite PPI adalah menganalisis data hasil laporan untuk ditindaklanjuti sebagai rekomendasi ke Direktur rumah sakit, memberikan umpan balik laporan ke unit-unit terkait, dan fungsi pengawasan terhadap tindakantindakan yang menyimpang dari standar prosedur/monitoring proses surveilans. Tim PPI belum memantau tindak lanjut laporan ke unit-unit terkait. Komite PPI. Hasil wawancara terstruktur dengan checklist tentang tugas dan tanggungjawab Komite dan Tim PPI sesuai Pedoman Manajerial PPI untuk Rumah Sakit dari Depkes tahun 2008, menunjukkan Komite PPI hanya melakukan 2 dari 8 tugas ( $25 \%$ ), IPCN hanya melakukan 1 dari 7 tugas $(14,3 \%)$ dan IPCLN belum melakukan tugasnya sesuai pedoman tersebut. Sebagian besar perawat IPCLN belum mengetahui tugas dan tanggungjawabnya sebagai Tim PPI karena sejak dibuatkan SK Direktur tahun 2010 belum ada sosialisasi menyeluruh ke semua unit pelayanan terkait, bahkan ada yang belum tahu penunjukan mereka sebagai IPCLN.

\section{Dukungan Manajemen}

Hasil wawancara terstruktur dengan checklist terhadap Tim PPI (perawat IPCN dan IPCLN) sebanyak 19 orang tentang dukungan kebijakan manajemen (Tabel 1.) menunjukkan $63,2 \%$ responden belum mengetahui uraian tugas dan wewenang sebagai Tim PPI; 78,95\% pelaksana surveilans belum cukup mewakili semua unit di rumah sakit; 68,4\% menyatakan belum lengkapnya fasilitas dan sarana yang disediakan rumah sakit untuk menunjang kegiatan surveilans; 63,2\% menyatakan belum adanya prosedur/ketentuan tentang evaluasi pelaksanaan surveilans. Responden juga menyatakan hal-hal yang sudah dilakukan oleh manajemen adalah penetapan prosedur atau dokumen kebijakan tentang pembentukan Komite dan Tim PPI sebanyak 68,4\% responden, dan sudah adanya kebijakan dengan pembuatan Surat Keputusan Direktur tentang Komite dan Tim PPI sebanyak 89,5\% responden. Hasil analisis terhadap hal-hal tersebut diatas menggambarkan belum maksimalnya dukungan manajemen (supporting system) terhadap program surveilans infeksi nosokomial di RSUD Dr. Iskak Tulungagung.

Tabel 1. Rekapitulasi hasil wawancara terstruktur dengan checklist tentang dukungan manajemen rumah sakit dalam program surveilans infeksi nosokomial terhadap tim PPI

\begin{tabular}{lllllc}
\hline No. & \multicolumn{1}{c}{ Pertanyaan } & $\begin{array}{c}\text { Jawaban } \\
\text { "ya" }\end{array}$ & $\%$ & $\begin{array}{c}\text { Jawaban } \\
\text { "tidak" }\end{array}$ & $\%$ \\
\hline 1. & $\begin{array}{l}\text { Apakah pelaksana surveilans } \\
\text { (IPCN dan IPCLN) }\end{array}$ & 8 & $42,1 \%$ & 11 & $57,9 \%$ \\
$\begin{array}{l}\text { mengetahui struktur } \\
\text { organisasi Komite PPI }\end{array}$ & & & & & \\
2. Apakah pelaksana surveilans \\
\begin{tabular}{l} 
(IPCN dan IPCLN) sudah \\
\hline
\end{tabular}
\end{tabular}


Tabel 1. Rekapitulasi hasil wawancara terstruktur dengan checklist tentang dukungan manajemen rumah sakit dalam program surveilans infeksi nosokomial terhadap tim PPI (Lanjutan)

\begin{tabular}{|c|c|c|c|c|c|}
\hline No. & Pertanyaan & $\begin{array}{c}\text { Jawaban } \\
\text { "ya" }\end{array}$ & $\%$ & $\begin{array}{c}\text { Jawaban } \\
\text { "tidak" }\end{array}$ & $\%$ \\
\hline & $\begin{array}{l}\text { mengetahui uraian tugas dan } \\
\text { wewenang sebagai } \\
\text { pelaksana program PPI }\end{array}$ & & & & \\
\hline 3. & $\begin{array}{l}\text { Apakah Tim PPI mengetahui } \\
\text { rencana kegiatan Komite PPI } \\
\text { tentang kegiatan surveilans } \\
\text { infeksi nosokomial }\end{array}$ & 13 & $68,4 \%$ & 6 & $31,6 \%$ \\
\hline 4. & $\begin{array}{l}\text { Apakah pelaksana surveilans } \\
\text { (IPCLN) sudah cukup } \\
\text { mewakili semua unit di RS }\end{array}$ & 4 & $21,05 \%$ & 15 & $\begin{array}{c}78,95 \\
\%\end{array}$ \\
\hline 5. & $\begin{array}{l}\text { Apakah ada fasilitas dan } \\
\text { sarana yang disediakan } \\
\text { manajemen untuk } \\
\text { menunjang kegiatan } \\
\text { surveilans infeksi nosokomial }\end{array}$ & 6 & $31,6 \%$ & 13 & $68,4 \%$ \\
\hline 6. & $\begin{array}{l}\text { Apakah ada } \\
\text { prosedur/ketentuan tentang } \\
\text { organisasi PPI (dokumen } \\
\text { kebijakan tentang } \\
\text { pembentukan Komite PPI) }\end{array}$ & 14 & $73,7 \%$ & 5 & $26,3 \%$ \\
\hline 7. & $\begin{array}{l}\text { Apakah ada } \\
\text { prosedur/ketentuan tentang } \\
\text { evaluasi pelaksanaan } \\
\text { surveilans. }\end{array}$ & 7 & $36,8 \%$ & 12 & $63,2 \%$ \\
\hline 8. & $\begin{array}{l}\text { Apakah ada } \\
\text { dukungan/kebijakan } \\
\text { manajemen dengan Surat } \\
\text { Keputusan Direktur tentang } \\
\text { anggota Komite \& Tim PPI }\end{array}$ & 17 & $89,5 \%$ & 2 & 10,5 \\
\hline
\end{tabular}

\section{Akar Penyebab Masalah dan Alternatif Solusi}

Hasil brainstorming melalui FGD dengan IPCN dan IPCLN untuk mencari akar masalah dengan bantuan diagram Fishbonelshikawamenemukan akar masalah dari cabang sirip ikan, dilanjutkan dengan pertanyaan " 5 Why" terhadap cabang sirip ikan untuk menemukan akar penyebab masalah pada Tabel 2 .

Berdasarkan hasil brainstorming dengan metode " 5 Why" tersebut ditemukan 3 akar penyebab masalah ditunjukkan pada Tabel 3. Selanjutnya dilakukan brainstrorming dengan manajemen rumah sakit dan Komite PPI dengan mengusulkan masing-masing 3 alternatif solusi pada setiap akar masalah, yang akan ditapis lagi untuk menetapkan solusi terbaik.

Tabel 3. Penetapan akar penyebab masalah dan alternatif solusi

\begin{tabular}{ll}
\hline No. Akar Penyebab Masalah & Alternatif Solusi \\
\hline
\end{tabular}

1. Belum ada kebijakan untuk sosialisasi program kesemua pelaksana surveilans infeksi nosokomial
1. Pembuatan SK kepada semua pelaksana program PPI dan mensosialisasikannya.

2. Mengadakan program pendidikan dan pelatihan secara berkesinambungan kepada Tim PPI

3. Menerapkan komunikasi dan koordinasi yang baik antara Komite dan Tim PP

Tabel 2. Rumusan akar penyebab masalah dengan pertanyaan " 5 Why"

\begin{tabular}{|c|c|c|c|c|c|c|c|}
\hline No. & Faktor & Rumusan Masalah & Whyl & Why II & Why III & Why IV & Why V \\
\hline \multirow[t]{2}{*}{1.} & Manpower & $\begin{array}{l}\text { Sebagian petugas } \\
\text { tidak tahu sebagai } \\
\text { Tim PPI }\end{array}$ & $\begin{array}{l}\text { Pelaksana } \\
\text { program belum } \\
\text { semua mendapat } \\
\text { SK penunjukan } \\
\text { sebagai Tim PPI }\end{array}$ & $\begin{array}{l}\text { Belum ada } \\
\text { sosialisasi } \\
\text { program } \\
\text { kepada Tim PPI }\end{array}$ & $\begin{array}{l}\text { Pembuatan SK } \\
\text { Tim PPI hanya } \\
\text { untuk dokumen } \\
\text { akreditasi }\end{array}$ & $\begin{array}{l}\text { Belum maksimalnya } \\
\text { dukungan anggaran } \\
\text { untuk } \\
\text { pertemuan/rapat } \\
\text { rutin. }\end{array}$ & $\begin{array}{l}\text { Belum ada } \\
\text { kebijakan untuk } \\
\text { sosialisasi } \\
\text { program } \\
\text { surveilans kepada } \\
\text { Tim PPI }\end{array}$ \\
\hline & & $\begin{array}{l}\text { Tim PPI (IPCN) } \\
\text { belum bekerja full } \\
\text { time }\end{array}$ & $\begin{array}{l}\text { Masih } \\
\text { merangkap tugas } \\
\text { lain (Karu/ } \\
\text { perawat ruang ) }\end{array}$ & $\begin{array}{l}\text { Kompetensi } \\
\text { Tim PPI belum } \\
\text { diutamakan }\end{array}$ & $\begin{array}{l}\text { Dianggap bisa } \\
\text { dilakukan oleh } \\
\text { perawat senior } \\
\text { yang ditunjuk }\end{array}$ & $\begin{array}{l}\text { Belum ada } \\
\text { perencanaan } \\
\text { rekruitmen staf }\end{array}$ & $\begin{array}{l}\text { Belum ada } \\
\text { dukungan } \\
\text { anggaran untuk } \\
\text { rekruitmen staf }\end{array}$ \\
\hline \multirow[t]{2}{*}{2.} & Method & $\begin{array}{l}\text { Pedoman/SPO } \\
\text { surveilans belum } \\
\text { disosialisasikan } \\
\text { kesemua } \\
\text { pelaksana/IPCLN }\end{array}$ & $\begin{array}{l}\text { Belum ada } \\
\text { perintah } \\
\text { manajemen } \\
\text { untuk sosialisasi } \\
\text { program }\end{array}$ & $\begin{array}{l}\text { Hanya untuk } \\
\text { keperluan } \\
\text { dokumen } \\
\text { akreditasi }\end{array}$ & $\begin{array}{l}\text { Sebagai syarat } \\
\text { kelengkapan } \\
\text { dokumentasi } \\
\text { program PPI }\end{array}$ & $\begin{array}{l}\text { Pedoman dan SPO } \\
\text { hanya diketahui } \\
\text { Komite PPI dan } \\
\text { sebagian Tim PPI saja }\end{array}$ & $\begin{array}{l}\text { Belum ada } \\
\text { kebijakan untuk } \\
\text { sosialisasi } \\
\text { pedoman /SPO } \\
\text { kepada pelaksana } \\
\text { IPCLN }\end{array}$ \\
\hline & & $\begin{array}{l}\text { Belum ada reward } \\
\text { and punishment } \\
\text { bagi pelaksana } \\
\text { program } \\
\text { surveilans }\end{array}$ & $\begin{array}{l}\text { Manajemen } \\
\text { belum } \\
\text { menjadikan PPI } \\
\text { sebagai program } \\
\text { prioritas }\end{array}$ & $\begin{array}{l}\text { Infeksi } \\
\text { nosokomial } \\
\text { dianggap belum } \\
\text { menjadi } \\
\text { masalah yang } \\
\text { penting }\end{array}$ & $\begin{array}{l}\text { Belum ada } \\
\text { laporan kejadian } \\
\text { Infeksi } \\
\text { nosokomial yang } \\
\text { serius dari } \\
\text { petugas } \\
\text { surveilans }\end{array}$ & $\begin{array}{l}\text { Pelaksana surveilans } \\
\text { tidak menjalankan } \\
\text { fungsi pencatatan } \\
\text { dan pelaporan } \\
\text { dengan baik }\end{array}$ & $\begin{array}{l}\text { Belum ada fungsi } \\
\text { pengawasan } \\
\text { terhadap } \\
\text { kepatuhan } \\
\text { pelaksanaan } \\
\text { surveilans }\end{array}$ \\
\hline 3. & Machine & $\begin{array}{l}\text { SIM dan software } \\
\text { khusus surveilans } \\
\text { belum ada }\end{array}$ & $\begin{array}{l}\text { Pengadaan SIM } \\
\text { dan software } \\
\text { dianggap belum } \\
\text { perlu }\end{array}$ & $\begin{array}{l}\text { PPI belum } \\
\text { menjadi } \\
\text { program } \\
\text { prioritas }\end{array}$ & $\begin{array}{l}\text { Dianggap tidak } \\
\text { memberikan } \\
\text { daya ungkit bagi } \\
\text { pendapatan RS }\end{array}$ & $\begin{array}{l}\text { Pengadaan SIM dan } \\
\text { software dirasa } \\
\text { mahal }\end{array}$ & $\begin{array}{l}\text { Belum ada } \\
\text { kebijakan } \\
\text { perencanaan } \\
\text { anggaran untuk } \\
\text { SIM }\end{array}$ \\
\hline
\end{tabular}


Tabel 2. Rumusan akar penyebab masalah dengan pertanyaan " 5 Why" (Lanjutan)

\begin{tabular}{|c|c|c|c|c|c|c|c|}
\hline No. & Faktor & Rumusan Masalah & Why I & Why II & Why III & Why IV & Why V \\
\hline \multirow[t]{2}{*}{4.} & Material & $\begin{array}{l}\text { Kantor sekretariat } \\
\text { dan } \\
\text { kelengkapannya } \\
\text { belum ada } \\
\text { (komputer, ATK, } \\
\text { sekretaris) }\end{array}$ & $\begin{array}{l}\text { dijadikan satu } \\
\text { dengan kantor } \\
\text { administrasi RS }\end{array}$ & $\begin{array}{l}\text { Kegiatan } \\
\text { pencatatan \& } \\
\text { pelaporan } \\
\text { dianggap } \\
\text { bagian } \\
\text { administrasi }\end{array}$ & $\begin{array}{l}\text { Manajemen } \\
\text { belum } \\
\text { memahami tugas } \\
\text { dan manfaat } \\
\text { surveilans untuk } \\
\text { menjamin mutu } \\
\text { pelayanan }\end{array}$ & $\begin{array}{l}\text { Hanya tuntutan } \\
\text { akreditasi tahun } \\
2010\end{array}$ & $\begin{array}{l}\text { Belum ada } \\
\text { dukungan } \\
\text { manajemen } \\
\text { terhadap sarana } \\
\text { penunjang } \\
\text { surveilans }\end{array}$ \\
\hline & & $\begin{array}{l}\text { rmulir laporan } \\
\text { n SOP belum } \\
\text { igkap diterima } \\
\text { semua unit }\end{array}$ & $\begin{array}{l}\text { Hanya diketahui } \\
\text { oleh Komite dan } \\
\text { sebagian Tim PPI }\end{array}$ & $\begin{array}{l}\text { Tidak ada } \\
\text { perintah } \\
\text { disosialisasikan } \\
\text { kepada seluruh } \\
\text { pelaksana } \\
\text { surveilans }\end{array}$ & $\begin{array}{l}\text { Hanya dibuat } \\
\text { untuk kebutuhan } \\
\text { penilaian } \\
\text { akreditasi }\end{array}$ & $\begin{array}{l}\text { Tuntutan kebutuhan } \\
\text { akreditasi sebatas } \\
\text { dokumen saja }\end{array}$ & $\begin{array}{l}\text { Belum ada } \\
\text { kebijakan untuk } \\
\text { sosialisasi SOP dan } \\
\text { distribusi formulir } \\
\text { kesemua unit } \\
\text { rawat inap }\end{array}$ \\
\hline \multirow{2}{*}{\multicolumn{2}{|c|}{ 5. Management }} & $\begin{array}{l}\text { Kebijakan } \\
\text { program PPI } \\
\text { belum } \\
\text { disosialisasikan } \\
\text { kesemua } \\
\text { pelaksana }\end{array}$ & $\begin{array}{l}\text { Tidak ada } \\
\text { kebijakan untuk } \\
\text { disosialisasikan } \\
\text { kepada seluruh } \\
\text { pelaksana } \\
\text { surveilans }\end{array}$ & $\begin{array}{l}\text { Hanya dibuat } \\
\text { untuk } \\
\text { kebutuhan } \\
\text { penilaian } \\
\text { akreditasi }\end{array}$ & $\begin{array}{l}\text { Tuntutan } \\
\text { kebutuhan } \\
\text { akreditasi tahun } \\
2010 \text { sebatas } \\
\text { dokumen saja }\end{array}$ & $\begin{array}{l}\text { Manajemen } \\
\text { memandang belum } \\
\text { perlu sosialisasi } \\
\text { program surveilans }\end{array}$ & $\begin{array}{l}\text { Kurangnya } \\
\text { dukungan } \\
\text { kebijakan } \\
\text { terhadap program } \\
\text { PPI }\end{array}$ \\
\hline & & $\begin{array}{l}\text { Monitoring dan } \\
\text { evaluasi program } \\
\text { surveilans belum } \\
\text { dilakukan }\end{array}$ & $\begin{array}{l}\text { Belum ada } \\
\text { koordinasi } \\
\text { antara penyusun } \\
\text { dan pelaksana }\end{array}$ & $\begin{array}{l}\text { Belum ada } \\
\text { kebijakan untuk } \\
\text { evaluasi } \\
\text { program PPI }\end{array}$ & $\begin{array}{l}\text { Belum } \\
\text { menjadikan } \\
\text { surveilans } \\
\text { sebagai prioritas }\end{array}$ & $\begin{array}{l}\text { Hanya sebatas } \\
\text { tuntutan akreditasi } \\
\text { RS tahun } 2010\end{array}$ & $\begin{array}{l}\text { Kurangnya } \\
\text { dukungan dan } \\
\text { pengawasan pada } \\
\text { program } \\
\text { surveilans }\end{array}$ \\
\hline
\end{tabular}

Tabel 3. Penetapan akar penyebab masalah dan alternatif solusi (Lanjutan)

\begin{tabular}{|c|c|c|}
\hline No. & Akar Penyebab Masalah & Alternatif Solusi \\
\hline 2. & $\begin{array}{l}\text { Kurangnya dukungan } \\
\text { manajemen terhadap } \\
\text { program dan sarana } \\
\text { penunjang surveilans } \\
\text { infeksi nosokomial }\end{array}$ & $\begin{array}{l}\text { 1. Menyediakan sekretariat PPI } \\
\text { dan } \begin{array}{l}\text { kelengkapannya } \\
\text { (komputer, Sistem Informasi }\end{array} \\
\text { Manajemen (SIM), dII) } \\
\text { 2. Menyediakan pedoman } \\
\text { pengisian formulir surveilans } \\
\text { dan Standar prosedur } \\
\text { operasional (SPO) kesemua } \\
\text { unit pelayanan terkait } \\
\text { 3. Merekruit tenaga IPCN yang } \\
\text { bekerja purna waktu (full time) }\end{array}$ \\
\hline 3. & $\begin{array}{l}\text { Belum ada fungsi } \\
\text { pengawasan terhadap } \\
\text { pelaksanaan program } \\
\text { surveilans infeksi } \\
\text { nosokomial }\end{array}$ & 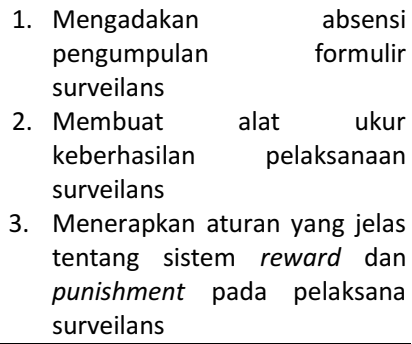 \\
\hline
\end{tabular}

Dari berbagai alternatif solusi pemecahan masalah yang telah disebutkan di atas, dicari dan dipilih alternatif solusi yang memiliki kontribusi dan daya ungkit terbesar untuk menyelesaikan masalah. Proses pemilihan prioritas solusi pemecahan masalah menggunakan tehnik Nominal Group Technique (NGT) dan disajikan pada tabel 4. NGT dilaksanakan tanpa pengaruh anggota yang lain yaitu semua anggota menuliskan skor masing-masing alternatif solusi sesuai kriteria berbobot (kemudahan penerapan $(0,2)$, kemungkinan berhasil $(0,2)$, efektifitas solusi $(0,5)$ dan hambatan relatif rendah $(0,1)$. Tapisan terhadap pilihan solusi berdasarkan hasil skor 1-5 yang terbanyak dipilih peserta dikalikan bobot sesuai kriteria kemudian dijumlahkan. Skor dan bobot masing-masing alternatif solusi dikalikan dan hasilnya dijumlahkan untuk menentukan rankingnya.

Berdasarkan 5 peringkat pemilihan alternatif solusi ditapis lagi dengan metode CARL (tabel 5) yang didasarkan pada serangkaian kriteria yang harus diberi skor 0-4. Kriteria tersebut meliputi: C=Capability (ketersediaan sumber daya misalnya dana, sarana, dan peralatan), $\mathrm{A}=$ Accessibility (kemudahan, masalah yang ada mudah diatasi atau tidak, kemudahan dapat didasarkan pada ketersediaan metode/cara/ teknologi serta penunjang pelaksana seperti peraturan), $\mathrm{R}=$ Readiness (kesiapan dari tenaga pelaksana maupun kesiapan sasaran, seperti keahlian atau kemampuan motivasi) dan L=Leverage (seberapa besar pengaruh kriteria yang satu dengan yang lain dalam pemecahan masalah yang dibahas). Berdasarkan metode tersebut terpilih skor tertinggi adalah mengadakan program pendidikan dan pelatihan secara berkesinambungan kepada tim PPI sebagai ujung tombak pelaksana surveilans infeksi nosokomial di RSUD dr. Iskak Tulungagung.

\section{DISKUSI}

Pendidikan dan Pelatihan sebagai Strategi Peningkatan Kinerja Tim PPI

Salah satu akar penyebab masalah rendahnya kinerja tim PPI adalah kurangnya sosialisasi program kepada tim PPI (IPCN dan IPCLN) sebagai pelaksana surveilans infeksi nosokomial di lapangan, meskipun sudah ditetapkan dengan SK penunjukan dari Direktur namun sebagian besar belum tahu tugas dan tanggungjawabnya. Hal ini 
Tabel 4. Tabel metode pemilihan solusi dengan metode NGT

\begin{tabular}{|c|c|c|c|c|c|c|}
\hline Pilihan solusi & $\begin{array}{c}\text { Kemudahan } \\
\text { penerapan } \\
(0,2)\end{array}$ & $\begin{array}{l}\text { Kemungkinan } \\
\text { berhasil } \\
(0,2)\end{array}$ & $\begin{array}{l}\text { Efektifitas } \\
\text { solusi } \\
(0,5)\end{array}$ & $\begin{array}{l}\text { Hambatan } \\
\text { relatif rendah } \\
(0,1)\end{array}$ & Nilai total & Ranking \\
\hline $\begin{array}{l}\text { 1. Pembuatan SK kepada semua pelaksana } \\
\text { program PPI dan mensosialisasikannya. }\end{array}$ & $\begin{array}{c}4 \\
(0,8)\end{array}$ & $\begin{array}{c}3 \\
(0,6)\end{array}$ & $\begin{array}{c}3 \\
(1,5)\end{array}$ & $\begin{array}{c}3 \\
(0,3)\end{array}$ & 3,2 & \\
\hline $\begin{array}{l}\text { 2. Mengadakan program pendidikan dan } \\
\text { pelatihan secara berkesinambungan } \\
\text { kepada Tim PPI }\end{array}$ & $\begin{array}{c}5 \\
(1,0)\end{array}$ & $\begin{array}{c}5 \\
(1,0)\end{array}$ & $\begin{array}{c}5 \\
(2,5)\end{array}$ & $\begin{array}{c}4 \\
(0,4)\end{array}$ & 4,9 & 1 \\
\hline $\begin{array}{l}\text { 3. Menerapkan komunikasi dan koordinasi } \\
\text { yang baik antara Komite dan Tim PPI }\end{array}$ & $\begin{array}{c}5 \\
(1,0)\end{array}$ & $\begin{array}{c}4 \\
(0,8)\end{array}$ & $\begin{array}{c}4 \\
(2,0)\end{array}$ & $\begin{array}{c}4 \\
(0,4)\end{array}$ & 4,2 & V \\
\hline $\begin{array}{l}\text { 4. Menyediakan kantor sekretariat PPI dan } \\
\text { kelengkapannya (komputer, SIMRS, } \\
\text { sekretaris) }\end{array}$ & $\begin{array}{c}5 \\
(1,0)\end{array}$ & $\begin{array}{c}5 \\
(1,0)\end{array}$ & $\begin{array}{c}5 \\
(2,5)\end{array}$ & $\begin{array}{c}3 \\
(0,3)\end{array}$ & 4,8 & II \\
\hline $\begin{array}{l}\text { 5. Menyediakan pedoman pengisian } \\
\text { formulir surveilans dan SPO kesemua } \\
\text { unit terkait }\end{array}$ & $\begin{array}{c}5 \\
(1,0)\end{array}$ & $\begin{array}{c}3 \\
(0,6)\end{array}$ & $\begin{array}{c}3 \\
(1,5)\end{array}$ & $\begin{array}{c}3 \\
(0,3)\end{array}$ & 3,4 & \\
\hline $\begin{array}{l}\text { 6. Merekruit tenaga IPCN yang bekerja } \\
\text { purna waktu (full time) }\end{array}$ & $\begin{array}{c}4 \\
(1,0)\end{array}$ & $\begin{array}{c}4 \\
(0,8)\end{array}$ & $\begin{array}{c}5 \\
(2,5)\end{array}$ & $\begin{array}{c}4 \\
(0,4)\end{array}$ & 4,7 & III \\
\hline $\begin{array}{l}\text { 7. Mengadakan absensi pengumpulan } \\
\text { formulir surveilans }\end{array}$ & $\begin{array}{c}3 \\
(0,6)\end{array}$ & $\begin{array}{c}3 \\
(0,6)\end{array}$ & $\begin{array}{c}4 \\
(2,0)\end{array}$ & $\begin{array}{c}3 \\
(0,3)\end{array}$ & 3,5 & \\
\hline $\begin{array}{l}\text { 8. Membuat alat ukur keberhasilan } \\
\text { pelaksanaan surveilans }\end{array}$ & $\begin{array}{c}5 \\
(1,0)\end{array}$ & $\begin{array}{c}3 \\
(0,6)\end{array}$ & $\begin{array}{c}2 \\
(1,0)\end{array}$ & $\begin{array}{c}2 \\
(0,2)\end{array}$ & 2,8 & \\
\hline $\begin{array}{l}\text { 9. Menerapkan aturan yang jelas tentang } \\
\text { sistem reward dan punishment pada } \\
\text { pelaksana surveilans }\end{array}$ & $\begin{array}{c}5 \\
(1,0)\end{array}$ & $\begin{array}{c}5 \\
(1,0)\end{array}$ & $\begin{array}{c}4 \\
(2,0)\end{array}$ & $\begin{array}{c}3 \\
(0,3)\end{array}$ & 4,3 & IV \\
\hline
\end{tabular}

terjadi karena jarangnya diadakan sosialisasi program melalui pendidikan dan pelatihan yang berkaitan dengan bimbingan teknis dan administrasi program surveilans infeksi nosokomial. Sebagian besar IPCLN menyatakan mendapat sosialisasi program saat awal dibentuk komite dan tim PPI pada tahun 2010 dalam rangka persiapan akreditasi rumah sakit saat itu, selanjutkan tidak diadakan lagi. Sebagian IPCLN dibeberapa ruang rawat inap yang sudah pernah mendapatkan pelatihan dan sosialisasi mengalami pergantian tugas karena mutasi/pindah bagian lain, sehingga kesinambungan kegiatan pengumpulan data dilanjutkan oleh perawat pengganti yang belum mendapatkan sosialisasi program sehingga tidak sesuai SOP dan pedoman yang berlaku.

Perawat IPCN yang terlatih (bersertifikat Pelatihan PPI Dasar) belum melakukan pengawasan terhadap tindakantindakan yang menyimpang dari standar prosedur dan memonitor proses surveilans terhadap IPCLN di ruang rawat inap/unit pelayanan terkait $\mathrm{PPI}$, karena kesibukan dan merangkap tugas sebagai perawat/kepala ruang rawat inap. Komite PPI belum mengidentifikasi temuan penyimpangan SPO pelaksanaan surveilans di lapangan dan belum mengusulkan program pelatihan untuk meningkatkan kemampuan sumber daya manusia (SDM) dibidang surveilans infeksi nosokomial.

Surveilans merupakan kegiatan yang dilaksanakan secara terus menerus dan sistematik dalam bentuk pengumpulan data, analisis data, interpretasi data dan diseminasi informasi maka perlu adanya pendidikan dan pelatihan berkesinambungan kepada pelaksana untuk bimbingan teknis dan evaluasi $(5,12,13)$. Karena metode yang dipakai adalah surveilans aktif dengan sasaran khusus (target surveillance) yang bertujuan untuk mendapatkan angka kejadian (jumlah kasus baru infeksi nosokomial dalam kurun waktu tertentu atas populasi yang berisiko), maka pengetahuan dan ketrampilan tim PPI dalam surveilans sangat diperlukan agar mendapatkan hasil yang akurat dan bisa dipertanggungjawabkan. Pendidikan dan pelatihan (Diklat) kepada tim PPI perlu dilakukan untuk membangun persamaan persepsi dan standar penilaian terhadap sasaran surveilans.

Mangkuprawira berpendapat bahwa pelatihan bagi karyawan adalah sebuah proses mengajarkan pengetahuan dan keahlian tertentu, serta sikap agar karyawan semakin trampil dan mampu dalam melaksanakan tanggung jawabnya dengan semakin baik sesuai dengan standar $(14,15)$. Dalam definisi lebih lanjut Mangkuprawira memberikan perbedaan pada pengertian

Tabel 5. Pemilihan alternatif solusi dengan metode CARL

\begin{tabular}{|c|c|c|c|c|c|c|}
\hline Alternatif Solusi & $\begin{array}{c}\text { Capability } \\
(1-4)\end{array}$ & $\begin{array}{c}\text { Accessibility } \\
(1-4)\end{array}$ & $\begin{array}{c}\text { Readiness } \\
(1-4)\end{array}$ & $\begin{array}{c}\text { Leverage } \\
(1-4)\end{array}$ & $\begin{array}{c}\text { Jumlah } \\
\text { skor }\end{array}$ & Ranking \\
\hline $\begin{array}{l}\text { 1. Mengadakan program pendidikan dan pelatihan secara } \\
\text { berkesinambungan kepada Tim PPI }\end{array}$ & 4 & 3 & 3 & 4 & 144 & $\mathbf{I}$ \\
\hline $\begin{array}{l}\text { 2. Menyediakan sekretariat PPI dan kelengkapannya (komputer, SIM, } \\
\text { sekretaris) }\end{array}$ & 3 & 3 & 3 & 2 & 54 & III \\
\hline 3. Merekruit tenaga IPCN yang bekerja purna waktu (full time) & 3 & 3 & 3 & 3 & 91 & II \\
\hline $\begin{array}{l}\text { 4. Menerapkan aturan sistem reward dan punishment pada } \\
\text { pelaksana surveilans }\end{array}$ & 3 & 2 & 3 & 2 & 36 & $\mathrm{~V}$ \\
\hline $\begin{array}{l}\text { 5. Menerapkan komunikasi dan koordinasi yang baik antara Komite } \\
\text { dan Tim PPI }\end{array}$ & 3 & 3 & 2 & 2 & 36 & IV \\
\hline
\end{tabular}


pelatihan dan pendidikan. Pelatihan lebih merujuk pada pengembangan ketrampilan bekerja (vocational) yang dapat digunakan dengan segera, sedangkan pendidikan memberikan pengetahuan tentang subyek tertentu, tetapi sifatnya lebih umum, terstruktur untuk jangka waktu yang jauh lebih panjang. Menurut Simamora pelatihan adalah proses sistematik yang mengubah perilaku para karyawan dalam suatu arah guna meningkatkan tujuan-tujuan organisasional (16). Terdapat tiga syarat yang harus dipenuhi dalam kegiatan pelatihan. Ketiga syarat tersebut adalah pelatihan harus membantu pegawai menambah pengetahuan dalam menjalankan tugasnya; pelatihan harus menimbulkan perubahan kebiasaan bekerja karyawan, sikapnya terhadap pekerjaan, informasi dan pengetahuan yang diterapkan dalam tugas; dan pelatihan harus berhubungan dengan pekerjaan tertentu (17). Tujuan pendidikan dan pelatihan antara lain: (1) untuk mengembangkan keterampilan sehingga pekerjaan dapat diselesaikan dengan lebih cepat dan lebih efektif, (2) untuk mengembangkan pengetahuan, sehingga pekerjaan dapat diselesaikan secara rasional, (3) untuk mengembangkan sikap, sehingga menimbulkan kemauan kerjasama dengan sesama pegawai dan pimpinan (17).

Rivai menyatakan fungsi pelatihan adalah memperbaiki kinerja (performance) para peserta. Pelatihan merupakan bagian pendidikan yang menyangkutproses belajar untuk memperoleh dan meningkatkan ketrampilan di luar sistem pendidikan yang berlaku dalam waktu yang relatif singkat dengan metode yang lebih mengutamakan pada praktik dari pada teori (18). Menurut Lembaga Administrasi Negara program pendidikan dan pelatihan merupakan sarana pembinaan dan pengembangan karir, melalui keikutsertaan dalam program pendidikan dan pelatihan maka pegawai terpilih secara sadar dan berencana dipersiapkan oleh organisasinya untuk menerima tanggung jawab pekerjaan yang berbeda (rotasi) dan atau kedudukan/jabatan yang lebih tinggi (promosi) pada waktu yang akan datang (future oriented), dan karenanya program pendidikan dan pelatihan merupakan salah satu investasi sumber daya manusia (human invesment) yang sangat berharga bagi setiap organisasi pemerintah $(18,19)$. Penyelenggaraan pendidikan dan pelatihan merupakan salah satu upaya untuk meningkatkan kualitas sumber daya manusia sesuai dengan kebutuhan pekerjaan pada setiap unit kerja (15).

\section{Dukungan Manajemen Rumah Sakit terhadap Kinerja PPI}

Menurut Swanburg salah satu fungsi manajemen adalah memimpin sebagai proses pendelegasian, pengawasan, koordinasi dan pengendalian implementasi rencana organisasi (20). Fokusnya adalah membimbing dan meningkatkan motivasi dengan upaya yang dilakukan yaitu: membuat sistem penghargaan, memberikan umpan balik positif, mengintegrasikan tujuan organisasi dengan staf/individu, mengurangi ketidakpuasan kerja, mendukung sumber daya (SDM, persediaan dan perlengkapan, program Diklat, dan sebagainya). Di RSUD Dr. Iskak Tulungagung belum ada dukungan yang maksimal terhadap program surveilans infeksi nosokomial karena tidak disediakannya ruang sekretariat PPI sehingga kegiatan PPI belum bisa terorganisir dengan baik. Proses pengumpulan data, analisa data, interpretasi data dilakukan oleh unit lain (Rekam Medik) yang petugasnya belum ikut pelatihan surveilans sehingga hasil informasi yang diperoleh masih diragukan kebenarannya. RSUD Dr.
Iskak Tulungagung sudah menerbitkan SK untuk Komite dan Tim PPI sejak tahun 2010, sudah membuat SOP pelaksanaan surveilans, namun belum disosialisasikan dengan baik kepada semua pelaksana. Sosialisasi program PPI melalui Diklat hanya dilakukan diawal pembentukan Komite dan Tim PPI, belum dilakukan repetisi untuk mengevaluasi kemampuan dan ketrampilan pelaksana program. Manajemen belum menunjuk IPCN yang bekerja purna waktu (full time), sehingga belum melakukan tugas dengan tanggungjawabnya dengan baik dalam kegiatan surveilans. Komite PPI belum menjalankan tugas dan tanggungjawabnya dalam memantau program surveilans dan belum melakukan pertemuan berkala termasuk evaluasi kebijakan.

Visi, misi dan tujuan dari PPI di rumah sakit merupakan bagian dari visi,misi dan tujuan rumah sakit itu sendiri yang perlu dirinci secara spesifik dalam lingkup pencegahan dan pengendalian infeksi di rumah sakit, sehingga dalam pelaksanaannya dapat saling sinergis, integratif, tidak duplikatif, efektif dan efisien $(3,5)$. Program PPI di rumah sakit merupakan bagian dari penerapan standar pelayanan rumah sakit sehingga keberhasilannya dapat ditampilkan sebagai kelengkapan akreditasi rumah sakit. Bentuk kebijakan manajemen rumah sakit adalah membentuk Komite PPI dan Tim PPI yang langsung berada dibawah koordinasi Direktur. Komite dan Tim PPI mempunyai tugas, fungsi, kewenangan yang jelas sesuai dengan Pedoman Manajerial Pencegahan dan Pengendalian Infeksi di Rumah Sakit dan Fasilitas Kesehatan Lainnya dari Depkes tahun 2008. Untuk lancarnya kegiatan PPI, maka setiap rumah sakit dan fasilitas kesehatan lainnya wajib memiliki IPCN purna waktu (5,11). Dukungan anggaran dari manajemen untuk kegiatan PPI dimanfaatkan untuk pengadaan pendidikan dan pelatihan (diklat), pengadaan fasilitas pendukung program, monitoring, evaluasi, laporan dan rapat rutin, juga untuk insentif/tunjangan (reward) untuk Komite PPI dan Tim PPI. Dukungan dana untuk melengkapi sarana, dan fasilitas pelayanan penunjang seperti kantor/ruang sekretariat, alat tulis kantor, komputer, telepon, internet, petugas sekretariat dan teknologi informasi (5).

\section{Fungsi Pengawasan dan Koordinasi pada Surveilans Infeksi Nosokomial}

Komite dan Tim PPI harus saling berkoordinasi terhadap fungsi pengawasan atau supervisi demi tercapainya tujuan kegiatan surveilans infeksi nosokomial sesuai pedoman. Komite PPI mengawasi kinerja IPCN dan IPCN mengawasi kinerja IPCLN di ruang rawat inap/unit pelayanan terkait dengan PPI. Jika tugas pengawasan tersebut dilaksanakan dengan baik akan mengurangi kesalahan menjalankan prosedur kerja surveilans infeksi nosokomial. Komite PPI RSUD Dr. Iskak Tulungagung belum melakukan fungsi pengawasan dengan baik terhadap tindakan-tindakan yang menyimpang dari standar prosedur/monitoring proses surveilans, dan hanya menerima hasil laporan dari Unit Rekam Medik. IPCN yang merangkap tugas sebagai perawat dan Kepala Ruang Rawat Inap belum mengawasi kinerja IPCLN terhadap kepatuhan pelaksanaan prosedur surveilans.

Secara umum yang dimaksud dengan supervisi adalah melakukan pengamatan secara langsung dan berkala oleh atasan terhadap pekerjaan yang dilaksanakan oleh bawahan. Kemudian apabila ditemukan masalah segera diberikan petunjuk atau bantuan yang bersifat langsung 
guna mengatasinya (21). Tujuan pokok dari supervise ialah menjamin pelaksanaan berbagai kegiatan yang telah direncanakan secara benar dan tepat, dalam arti lebih efektif dan efisien sehingga tujuan yang telah ditetapkan organisasi dapat dicapai dengan memuaskan (22).

Menurut Halley dalam Molina bahwa organisasi komite PPI bersifat independen dan mengikat seluruh komponen di rumah sakit, tapi mungkin membutuhkan pertimbangan dan penetapan dari otoritas yang lebih tinggi misalnya pejabat administrasi rumah sakit (6). Sejalan dengan hal ini perlu interaksi, koordinasi, kesadaran dan minat antar disiplin ilmu dan didukung oleh manajemen yang handal. Kendala yang dihadapi adalah komitmen pimpinan yang lemah dan kurangnya profesionalisme (5). Pimpinan selain direktur juga anggota komite dan tim PPI yang bertanggungjawab langsung pada program surveilans, ada rasa segan menegur senior, memberi penyuluhan/pendidikan kepada rekan yang lebih senior sebagai bawahan padahal mempunyai kewenangan. IPCN belum menggunakan wewenangnya untuk mempengaruhi orang lain (IPCLN) untuk menjalankan tugas dengan baik. Seorang IPCN dan IPCLN seharusnya menjadi pelopor atau "opinion leader" yang ditunjukkan dengan memberi pendidikan pada sesama rekan kerja dan bisa menunjukkan perubahan prilaku di ruang rawat inap (3). Oleh sebab itu perlu adanya sifat kepemimpinan yang menjadi budaya kerja. Kegiatan sosialisasi, pertemuan rutin yang disepakati bersama, tatap muka langsung antara pimpinan dan bawahan merupakan komunikasi sebagai proses transfer informasi adalah kunci untuk mendukung keberhasilan program (23). Jika tidak ada pertemuan berkala maka tidak bisa mengetahui evaluasi semua kegiatan program (benar-salah, baik-buruk) serta tidak tahu keberhasilan atau pencapaiannya. Tim PPI sebagai pelaksana langsung di lapangan membutuhkan pengawasan, motivasi dan umpan balik terhadap keberhasilan program (6).

Berdasarkan penelitian hasil survei yang dilakukan oleh Departemen Kesehatan RI bersama World Health Organization (WHO) ke rumah sakit-rumah sakit di

\section{DAFTAR PUSTAKA}

1. Haley RW, Culver DH, White JW, Morgan WM, and Emori TG. Original Contributions the Nation Nosocomial Infection Rate a New Need for Vital Statistic. The American Journal of Epidemiology. 1985; 121(2): 159-167.

2. Nejad SB, Allegranzi B, Syed SB, Ellis B, and Pittet D. Health-care-associated Infection in Africa: $A$ Systematic Review. Bulletin of the World Health Organization. 2011; 89: 757-765.

3. Dawson SJ. The Role of the Infection Control Link Nurse. Journal of Hospital Infection. 2003; 54(4): 251257.

4. Astrawinatan DAW. Epidemiologi Klinik dan Sistem Surveilans Infeksi di Rumah Sakit. [Materi Kursus]. Kursus Pengendalian Infeksi di Rumah Sakit. 2003.

5. Departemen Kesehatan Republik Indonesia. Pedoman Manajerial Pencegahan dan Pengendalian Infeksi di Rumah Sakit dan Fasilitas Pelayanan Kesehatan lainnya. Jakarta: Departemen Kesehatan $\mathrm{Rl} ; 2008$.
Propinsi/Kabupaten/Kota disimpulkan bahwa Komite Pencegahan dan Pengendalian Infeksi di Rumah Sakit (KPPIRS) selama ini belum berfungsi optimal sebagaimana yang diharapkan (24). Dari penelitian Permana dan Adisasmito tentang pelaksanaan tim PPI rumah sakit di Pelayanan Kesehatan St. Carolus Jakarta ditemukan masalah pada pelaksanaan tugas dan wewenang pelaksana harian masih belum optimal bisa dikatakan rendah. Ada unit tempat anggota pelaksana harian yang tidak memiliki pencatatan harian surveilans infeksi nosokomial sementara unit lain memilikinya. Rendahnya pengetahuan pelaksana harian tentang pengendalian infeksi nosokomial khususnya surveilans dapat menyebabkan tidak terlaksananya surveilans di unit-unit perawatan secara baik. Pelaksanaan surveilans yang tidak memenuhi persyaratan menyebabkan data angka infeksi nosokomial yang dapat diragukan kebenarannya. Seluruh informan (IPCN dan IPCLN) pada penelitian tersebut sependapat bahwa mereka mengalami kendala dalam pelaksanaan tugas dan fungsinya dalam Panitia Pengendalian Infeksi karena mempunyai tugas rangkap; kurangnya pengetahuan pribadi tentang tugas dan wewenang; rendahnya pendidikan, pengetahuan, sikap dan perilaku petugas di lapangan serta kurangnya referensi tentang surveilans infeksi nosokomial (24).

Surveilans infeksi nosokomial di RSUD Dr. Iskak Tulungagung belum dilakukan dengan baik sesuai Petunjuk Teknis Surveilans dari Depkes tahun 2010. Hal tersebut disebabkan belum adanya sosialisasi program yang berkesinambungan dengan pertemuan rutin, kurangnya pendidikan dan pelatihan tentang surveilans bagi tim PPI, kurangnya dukungan dan komitmen manajemen rumah sakit serta belum berperannya fungsi pengawasan dan koordinasi dari komite dan tim PPI. Hasil tapisan pilihan solusi terbaik dengan metode Nominal Group Technique (NGT) dan metode CARL adalah pengadaan program pendidikan dan pelatihan yang berkesinambungan pada Tim PPI untuk meningkatkan pengetahuan, ketrampilan dan sikap demi menunjang keberhasilan program surveilans infeksi nosokomial di rumah sakit.

6. Molina VF. Analisis Pelaksanaan Program Pencegahan dan Pengendalian Infeksi Nosokomial di Rumkital Dr. Mintohardjo Jakarta. [Tesis]. Universitas Indonesia, Jakarta. 2012.

7. Setiawati EP. Surveilans Infeksi Nosokomial. Bandung: Universitas Pajajaran Bandung; 2003.

8. Prabandari R. Analisis Pengaruh antara Pendidikan dan Latihan, Pengalaman Kerja, Inisiatif dan Motivasi Kerja terhadap Kinerja Tenaga Perawat di RS. Panti Wilasa Citarum Semarang. [Skripsi]. Universitas Katolik Soegijapranata, Semarang. 2003.

9. Amiruddin R. Surveilance Kesehatan Masyarakat. Bogor: IPB Press Bogor; 2012.

10. Departemen Kesehatan Republik Indonesia. Petunjuk Praktis Surveilans Infeksi Rumah Sakit. Jakarta: Departemen Kesehatan RI; 2010.

11. Sopirala MM, Yahle-Dunbar L, Smyer J, et al. Infection Control Link Nurse Program : An Interdiciplinary Approach and Targeting Health Care-Acquired Infection. American Journal of Infection Control. 2014; 42(4): 353-359. 
12. Dessler G. Manajemen Sumber Daya Manusia. Edisi ke-8. Jakarta: PT. Prenhalindo; 2009.

13. Rai N. Under Surveillance. Occupational Health. 2006; 58(5): 29-31.

14. Mangkuprawira S. Manajemen Sumber Daya Manusia Strategik. Jakarta: Ghalia Indonesia; 2004.

15. Farooq $\mathrm{M}$ and Khan MA. Impact Training and Feedback on Employaee Performance. Far East Journal of Psychologi and Business. 2011; 5(1): 23-33.

16. Simamora H. Manajemen Sumber Daya Manusia. Edisi ketiga. Yogyakarta: STIE YKPN; 2004.

17. Moekijat. Manajemen Personalia dan Sumber Daya Manusia. Bandung: Mandar Maju; 2003.

18. Rivai V. Manajemen Sumber Daya Manusia untuk Perusahaan, dari Teori ke Praktek. Edisi 1. Jakarta: PT. Raja Grafindo Persada; 2006.

19. Asim M. Impact Training of Motivation on Employee
Performance with Effect of Training: Specific to Education Sector of Pakistan. International Journal of Scientific and Research Publication. 2013; 3(9): 1-9.

20. Swanburg RC. Nursing Staff Development; $A$ Component of Human Resource Development. 2nd edition. London: Jones and Barlett Publisher; 2000.

21. Azwar A. Pengantar Administrasi Kesehatan. Edisi ketiga. Jakarta: Bina Rupa Aksara; 1996.

22. Suarli $S$ dan Bachtiar. Manajemen Keperawatan dengan Pendekatan Praktik. Jakarta: Erlangga; 2009.

23. Kapp KM. Transforming Your Manufacturing Organization Into a Learning Organization. Hospital Materiel Management Quarterly. 1999; 20(4): 46-54.

24. Permana LW dan Adisasmito W. Analisis Pelaksanaan Tugas dan Fungsi Panitia Pengendalian Infeksi Nosokomial Pelayanan Kesehatan St. Carolus Jakarta tahun 2004. Jurnal Manajemen Pelayanan Kesehatan. 2005; 8(2): 99-104. 